\title{
MODELLING AND SIMULATION OF A GRID-CONNECTED PHOTOVOLTAIC SYSTEM FOR AN MIDDLE-CLASS APARTMENT IN NEW ASSIUT CITY
}

\section{${ }^{1}$ Ahmed G. Abo-Khalil, ${ }^{2}$ Hammad Abo-Zied}

\author{
${ }^{1}$ Electrical Engineering Department, Almajmaah University, Saudi Arabia \\ ${ }^{2}$ Electrical Engineering Department, Assiut University, Egypt \\ E-mail: yassmen1@yahoo.com
}

(Received June 30, 2012 Accepted September 3, 2012)

\begin{abstract}
This paper presents the complete model and design of a grid-connected Photovoltaic (PV) system to supply electric power for an apartment in new Assiut city, Assiut province, Egypt according to its energy requirements. This system can be installed on the roof and the south side of the building. Homer software is used as the sizing and optimization tool to determine the size and specifications requirements of photovoltaic system components, system cost and estimation of corresponding produced electrical power. Simulation results and analyses are presented to validate the proposed system configuration.
\end{abstract}

Keywords: PV system and sizing, Homer software.

\section{INTRODUCTION}

Over the last two decades, there have been two major events that led the world's industrialized nations to look at renewable energy sources as a supplement to providing the projected increase in energy demand in their respective nations. These events include the world's energy crisis of the mid 1970s and the increased awareness of the effects of emissions from fossil fueled power plants to both humans and the environment. In order to ameliorate the potential harm from these emissions, governments in industrialized countries are currently debating and enacting pollution control regulations into laws. These laws are geared towards both small and large emission sources [1], [2].

Among a wide range of renewable energy projects in progress throughout the world, photovoltaic (PV) systems are the most promising as a future energy technology. The overall objective of photovoltaic technology is to obtain electricity from the sun that is cost competitive and even advantageous with respect to other energy sources. Photovoltaic generation is already a reality in some environments, but of their diffusion in rural areas, there still exists many constraints and the problem needs to be examined from the economic, technical, operational and institutional viewpoints [3].

Photovoltaic (PV) energy generating systems (or PV systems) convert the sun's energy directly into electricity using state-of-the-art semiconductor materials. PV systems vary in complexity. Some are called a "stand-alone or off-grid" system, which means they are the sole source of power to a home, water pump or other loads. Standalone systems can be designed to run with or without backup battery. Remote water 
pumps are often designed to run without battery backup, since water pumped out of the ground during daylight hours can be stored in a holding tank for use any time. In contrast, stand-alone home power systems often store energy generated during the day in a battery bank for use at night. Stand-alone systems are often cost-effective when compared to alternatives such as utility line extensions.

Other PV systems are called "grid-connected" systems. These work to supplement existing electric service from a utility company. When the amount of energy generated by a grid-connected PV system exceeds the customer's loads, excess energy is exported to the utility, turning the customer's electric meter backward. Conversely, the customer can draw needed power from the utility when energy from the PV system is insufficient to power the building's loads. Under this arrangement, the customer's monthly electric utility bill reflects only the net amount of energy received from the electric utility. Each type of system requires specific components besides the PV modules. Generating AC power requires a device called an inverter. The final cost of any PV system ultimately depends on the PV array size and on the other components required for the specific application [4].

This paper provides a design of a grid-connected PV system for an apartment in new Assiut city including suggested load profiles, sizing of a PV system for supplying an electrical load of the faculty. The design of the proposed system is based on Hybrid Optimization Model for Electric Renewable (Homer) software. Homer contains a number of energy component models and evaluates suitable technology options based on cost and availability of resource. Analysis with Homer requires information on economic constraints and different control methods. It also requires input on component types, their numbers, costs, efficiency, reliability, lifetime, etc. Sensitivity analysis could be done with variables having a range of number values instead of a specific number. This allows one to ascertain the effects of change in a certain parameter individually on the overall system [4].

\section{PV SYSTEM SIZING}

The standard area of the new apartments in the new cities of Egypt is about $120-\mathrm{m}^{2}$. The electrical loads of an average apartment consists of air-condition, four lamps, three fans, refrigerator, television, vacuum cleaner, washing machine, and computer. The total load demand of the apartment is about $5 \mathrm{KW}$ as shown in table I. However, these loads do not work all at one time on the contrary, working for a short time. 


\section{Table 1: Typical household electrical appliances}

\begin{tabular}{|c|c|}
\hline Appliance & Watts \\
\hline Ceiling Fan & $3 \times 100$ \\
\hline Computer & 200 \\
\hline Lights, 4 Fluorescents & $4 \times 40$ \\
\hline Refrigerator & 600 \\
\hline Television & 250 \\
\hline Vacuum Cleaner & 600 \\
\hline Washing Machine & 500 \\
\hline Air-Condition & 2283 \\
\hline Total Load & 5000 \\
\hline
\end{tabular}

The sizing procedure is designed corresponding to the data described in subsections as [5]:

\subsection{Radiation data}

The amount of useful sunshine available for the panels on an average day during the worst month of the year is called the "insolation value". The worst month is used for analysis to ensure the system will operate year-round. In Assiut, average solar insolation is 6.0 hours per day in December. The insolation value also can be interpreted as the kilowatt-hours per day of sunlight energy that fall on each square meter of solar panels at latitude tilt.

Table II shows the monthly average values of global solar radiation over Assiut [6]. It is clear from the table that solar energy incident on the region is very high especially during summer months with average daily radiation during June $8.01 \mathrm{KWh} / \mathrm{m} 2 /$ day.

Table 2: The monthly average values of daily global solar radiation

(Kwh/m/day) in Assiut city

\begin{tabular}{|c|c|}
\hline Month & $\begin{array}{c}\text { Daily Radiation in } \\
\text { Kwh/m2/day }\end{array}$ \\
\hline January & 3.18 \\
\hline February & 4.30 \\
\hline March & 5.60 \\
\hline April & 6.68 \\
\hline May & 7.39 \\
\hline June & 8.01 \\
\hline July & 7.93 \\
\hline August & 7.36 \\
\hline September & 6.34 \\
\hline October & 4.93 \\
\hline November & 3.73 \\
\hline December & 2.96 \\
\hline
\end{tabular}




\subsection{Load data in different seasons}

The preferred method for determining PV system loads is a "bottom-up" approach in which every daily load is anticipated and summed to yield an average daily total. For PV systems designed to power simple loads, such as a single fan, electric light or other appliance, this method is easy. Simply look at the nameplate power rating on the appliance to calculate its power consumption in watt.

Finally all the different loads in the building need to be estimated on a typical day and sum of them. Table III provides the calculations of the power and energy of an apartment in new Assiut city. The daily load profiles were determined by calculating the power demand (Kwh/day) for all load types in the department during the four seasons. The estimated daily energy consumption is given in Table III. It is shown that, summer has the highest energy consumption (18.985 KWh /day) compared to the other seasons. However, loads seem very close in the winter and spring. The average annual load energy is about $10 \mathrm{KWh} /$ day.

Table 3: The daily load energy consumption

\begin{tabular}{|c|c|c|c|c|c|c|c|c|c|c|}
\hline \multirow{2}{*}{$\begin{array}{l}\text { Load } \\
\text { type }\end{array}$} & \multirow{2}{*}{$\begin{array}{l}\text { No. } \\
\text { Of } \\
\text { units }\end{array}$} & \multirow{2}{*}{$\begin{array}{c}\text { Rated } \\
\text { power } \\
(\mathrm{W})\end{array}$} & \multicolumn{2}{|c|}{ Autumn } & \multicolumn{2}{|c|}{ Winter } & \multicolumn{2}{|c|}{ Spring } & \multicolumn{2}{|c|}{ Summer } \\
\hline & & & $\begin{array}{l}\text { Av.hrs } \\
\text { used/ } \\
\text { day }\end{array}$ & $\begin{array}{l}\text { KWh } \\
\text { / day }\end{array}$ & $\begin{array}{l}\text { Av.hrs } \\
\text { used/ } \\
\text { day }\end{array}$ & $\begin{array}{l}\text { KWh } \\
\text { / day }\end{array}$ & $\begin{array}{c}\text { Av.hrs } \\
\text { used/ } \\
\text { Day }\end{array}$ & $\begin{array}{l}\text { KWh } \\
\text { / day }\end{array}$ & $\begin{array}{l}\text { Av.hrs } \\
\text { used/ } \\
\text { day }\end{array}$ & $\begin{array}{l}\text { KWh } \\
\text { / day }\end{array}$ \\
\hline Ceiling Fan & 3 & $3 \times 100$ & 2 & 0.6 & - & - & - & - & 4 & 1.2 \\
\hline Computer & 1 & 200 & 6 & 1.2 & 6 & 1.2 & 6 & 1.2 & 6 & 1.2 \\
\hline Lights & 4 & $4 \times 40$ & 5 & 0.8 & 6 & 0.96 & 5 & 0.8 & 5 & 0.8 \\
\hline Refrigerator & 1 & 600 & 4 & 2.4 & 3 & 1.8 & 3 & 1.8 & 5 & 3.0 \\
\hline Television & 1 & 250 & 5 & 1.25 & 4 & 1.0 & 4 & 1.0 & 4 & 1.0 \\
\hline $\begin{array}{l}\text { Vacuum } \\
\text { Cleaner }\end{array}$ & 1 & 600 & 0.2 & 0.12 & 0.2 & 0.12 & 0.2 & 0.12 & 0.2 & 0.12 \\
\hline $\begin{array}{l}\text { Washing } \\
\text { Machine }\end{array}$ & 1 & 500 & 1 & 0.5 & 0.5 & 0.25 & 0.5 & 0.25 & 0.5 & 0.25 \\
\hline $\begin{array}{c}\text { Air- } \\
\text { Condition }\end{array}$ & 1 & 2283 & 2 & 4.566 & - & - & - & - & 5 & 11.415 \\
\hline & & 5000 & & 11.43 & & 5.33 & & 5.17 & & 18.985 \\
\hline
\end{tabular}

\subsection{PV Array Size and Cost}

For a PV system powering loads that will be used every day, the size of the array is determined by the daily energy requirement divided by the sun-hours per day. For systems designed for non-continuous use (such as schools, governmental offices, etc.), multiply the result by the days per week the loads will be active divided by the total number of days in the week. Generally, grid-connected systems are designed to provide from 10 to $60 \%$ of the energy needs with the difference being supplied by utility power. In this paper we take the ratio of $60 \%$ of the needed energy to be covered by the PVs. So, the total power of the PV system is about $3 \mathrm{KW}$.

Many PV modules can be purchased at retail for about $\$ 4.5$ per watt for most medium systems in the 3,000 watt range. Of course, there are opportunities to purchase modules for a lower price, especially when your system is larger and you can buy in bulk. An inverter will be needed for systems that output AC power. For stand-alone systems the inverter should be sized to provide $125 \%$ of the maximum loads you wish 
to run simultaneously at any one moment. Inverters are designed for residences and other small systems. These inverters can be purchased at retail for about $\$ 2$ per rated watt.

\subsection{Homer Analysis}

Figure 1 shows the proposed scheme as implemented in the Homer simulation tool. A grid-connected PV system consists of a primary energy source, power inverter to maintain the flow of energy between the AC and DC sides and the grid-utility. This configuration is a grid-connected PV system that supplies the electrical energy to the load with the lowest net present cost. Figure 2 shows the optimization result for the given solar radiation in Assiut, load data, economics and constraints, Homer simulates one optimal configuration from the given search space.

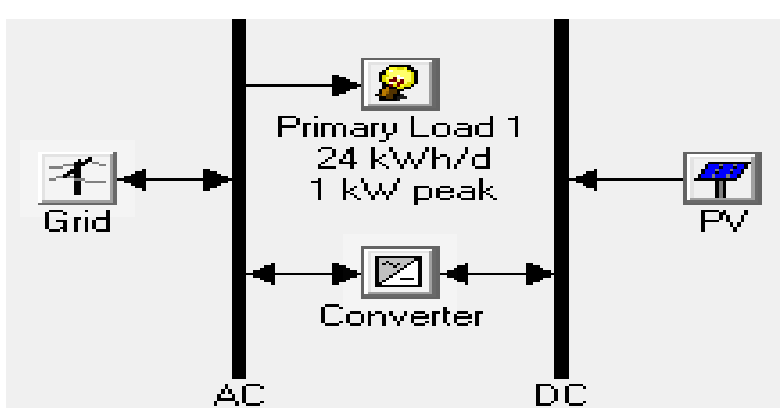

Fig.1. Homer implementation of the stand-alone PV System

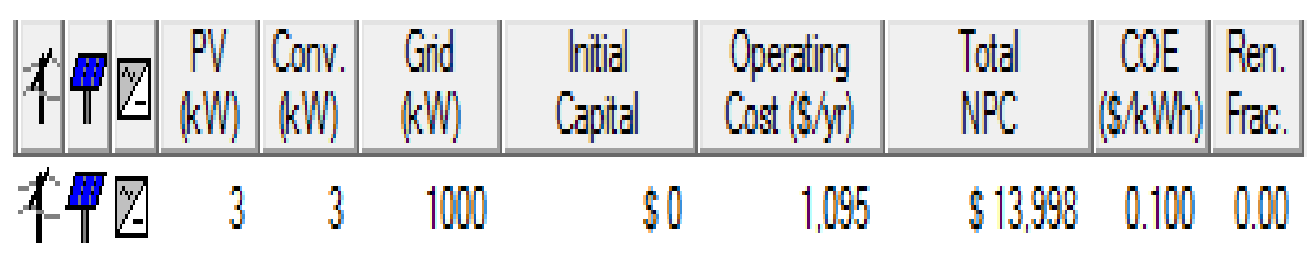

Fig.2. The optimization result of homer

\section{3- SOLAR ARRAY EQUIVALENT CIRCUIT AND ITS CHARACTERISTICS}

Solar cells are devices that convert photons into electrical potential in a PN junction, of which equivalent circuit is shown in Fig. 3 [3]. Due to the complex physical phenomena inside the solar cell, manufacturers usually present a family of operating curves (V-I) as shown in Fig. 4. These characteristics are obtained by measuring the array volt-ampere for a different illumination values. From these characteristics, the optimum voltage or current, corresponding to the maximum power point, can be determined. It is clearly seen in Fig. 4 that the current increases as the irradiance levels increase. The maximum power point increases with a steep positive slope proportional to the illumination. 


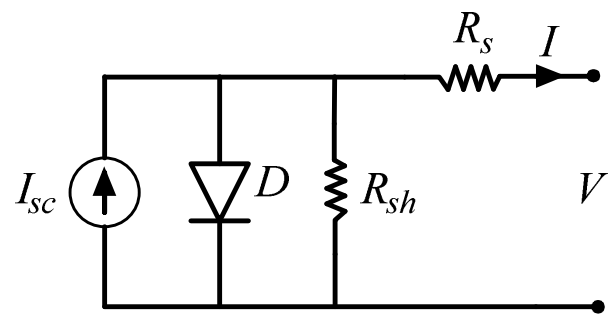

Fig. 3 Equivalent circuit of PV array.

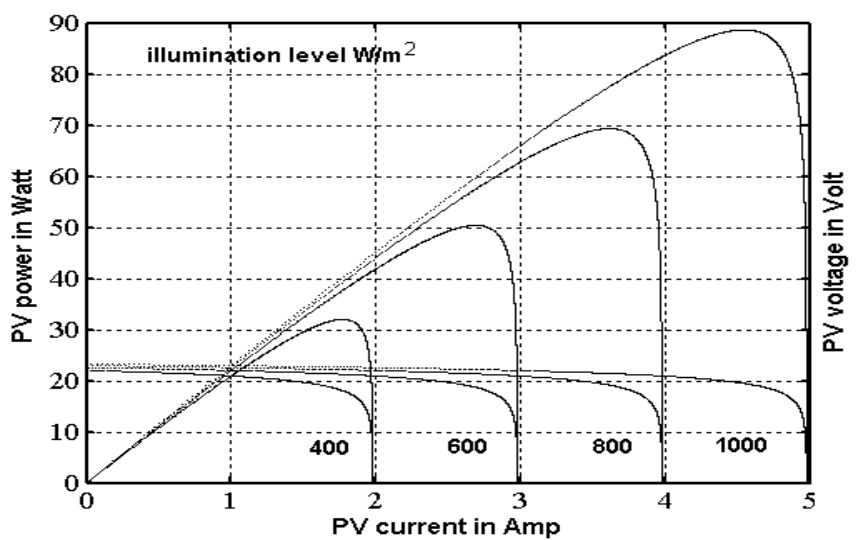

Fig. 4 V-I and P-I characteristics of PV at constant temperature.

The main parameters which influence the illumination levels on a surface at a fixed tilt on earth are the daily and seasonal solar path, the presence of clouds, mist, smog and dust between the surface and the sunlight, and the shade of the object positioned such that the illumination level is reduced, etc.

The equation of the PV output current $I$ is expressed as a function of the array voltage $V[3]$

$$
I=I_{\mathrm{sc}}-I_{\mathrm{o}}\left\{e^{\frac{q\left(V+I R_{\mathrm{s}}\right)}{K T_{k}}}-1\right\}-\left(V+I R_{\mathrm{s}}\right) / R_{\mathrm{sh}}
$$

where $V$ and $I$ represent the PV output voltage and current, respectively; $R_{s}$ and $R_{s h}$ are the series and

shunt resistance of the cell (in Fig. 3); $q$ is the value of charge of electron; $I_{s c}$ is the light-generated current; $\mathrm{I}_{\mathrm{o}}$ is the reverse saturation current; $K$ is the Boltzman constant, and $T_{k}$ is the temperature in $K$.

Equation (1) can be rewritten as [7]

$I=I_{s c}\left\{1-K_{1}\left[e^{K_{2} V^{m}}-1\right]\right\}-\left(V+I R_{\mathrm{s}}\right) / R_{\mathrm{sh}}$

where the coefficient $K_{1}, K_{2}$ and $\mathrm{m}$ are defined as

$K_{1}=0.01175$, 
$K_{2}=K_{4} /\left(V_{o c}\right)^{m}$,

And $m=\ln \left(K_{3} / K_{4}\right) / \ln \left(V_{m p p} / V_{o c}\right)$

where

$K_{4}=\ln \left(\left(K_{1}+1\right) / K_{1}\right)$,

$K_{3}=\ln \left[\left(I_{s c}\left(1+K_{1}\right)-I_{m p p}\right) / K_{1} I_{s c}\right]$,

$I_{m p p}$ is the current at maximum output power, $V_{m p p}$ is the voltage at maximum power, $I_{s c}$ is the short circuit current and $V_{o c}$ is the open circuit voltage of the array.

Equation (2) is only applicable at one particular operating condition of illumination $G$ and cell temperature $T_{c}$. The parameter variations can be calculated by measuring the variation of the short-circuit current and the open-circuit voltage in these conditions using the parameters at the normal illumination and cell temperature. Equation (2) is used for the $I-V$ and $P-V$ characteristics for various illuminations and fixed temperature $\left(25\left[{ }^{\circ} \mathrm{C}\right]\right)$ as shown in Fig. 4.

\section{4- SYSTEM DESCRIPTION}

A conventional two-stage energy conversion system is connected between the PV array and the electrical power system as shown in Fig. 5. A boost converter is used to increase the PV voltage for the inverter circuit and it also plays a role of an intermediate circuit for tracking the maximum power point.

The inverter circuit converts the direct current to the alternating current which flows into the utility or local loads. The inverter controller has two main functions. One is to synchronize the output current with the grid voltage, which means the power factor is equal to unity. The other is that it controls the dc link voltage. To achieve these two goals, the inner current control loop and the outer voltage control loop are used as shown in Fig 6. The whole control circuit is shown in Fig. 6, the P\&O controller for maximum power point tracking (MPPT) generates pulse width modulation (PWM ) gating signal for the converter switch.

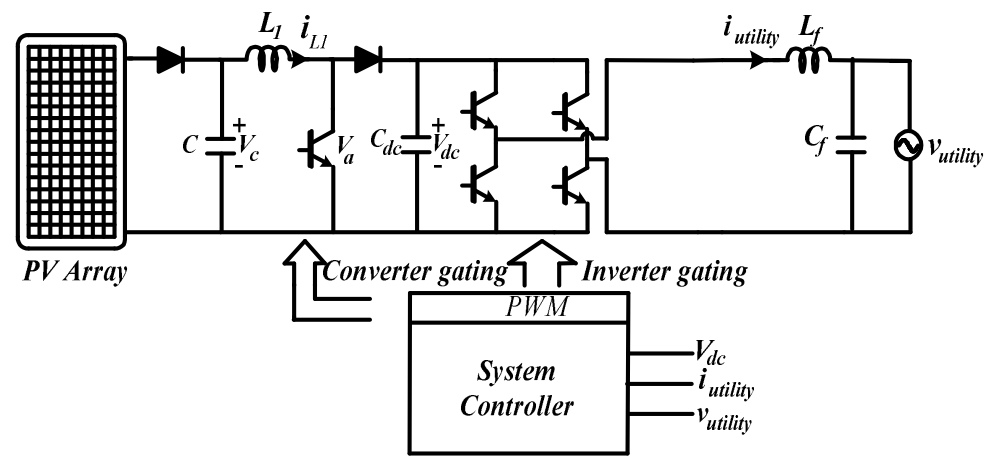

Fig. 5. Power circuit for PV system. 


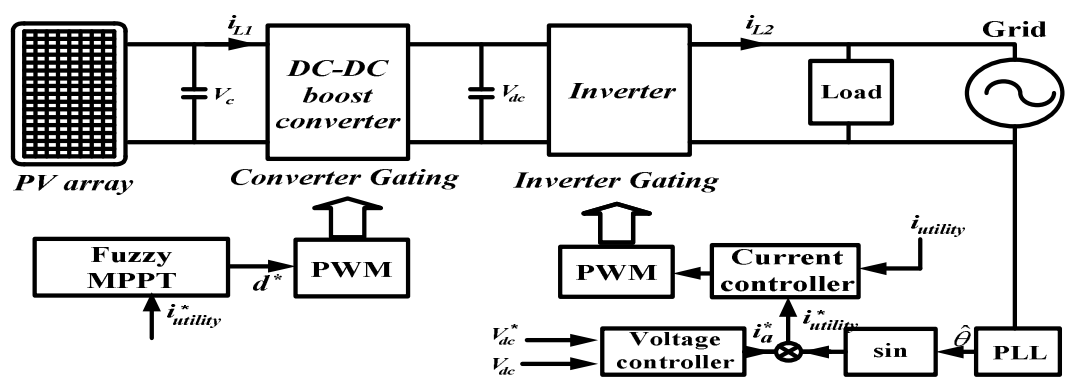

Fig. 6. Control circuit for the PV system.

\section{5- SiMULATION RESULTS}

The full detailed model of the proposed single-phase grid-connected PV energy conversion system is implemented in the PSIM software environment as depicted in Fig. 7. Figure 8 shows that the output power changes according to the illumination variation from $800[\mathrm{w} / \mathrm{m} 2]$ to $700[\mathrm{w} / \mathrm{m} 2]$ to $600[\mathrm{w} / \mathrm{m} 2]$. The new incremental duty ratio varies according to the change in dc-ac inverter reference current. These relations between the input and output are determined in the base-rule form. It is noticed that the fast dynamic performance at step variation of illumination level is obtained.

Figure 9 shows the unity power factor operation of the grid current and voltage waveforms. From this figure, the grid voltage and current are pure sinusoidal without harmonics and phase difference. Figure 10 shows the dynamic response of the dc link voltage and the inverter reference current. This figure shows excellent dynamic response despite the rapid change in the illumination level and power. Also, the conversion system provides smooth and stable operation. 


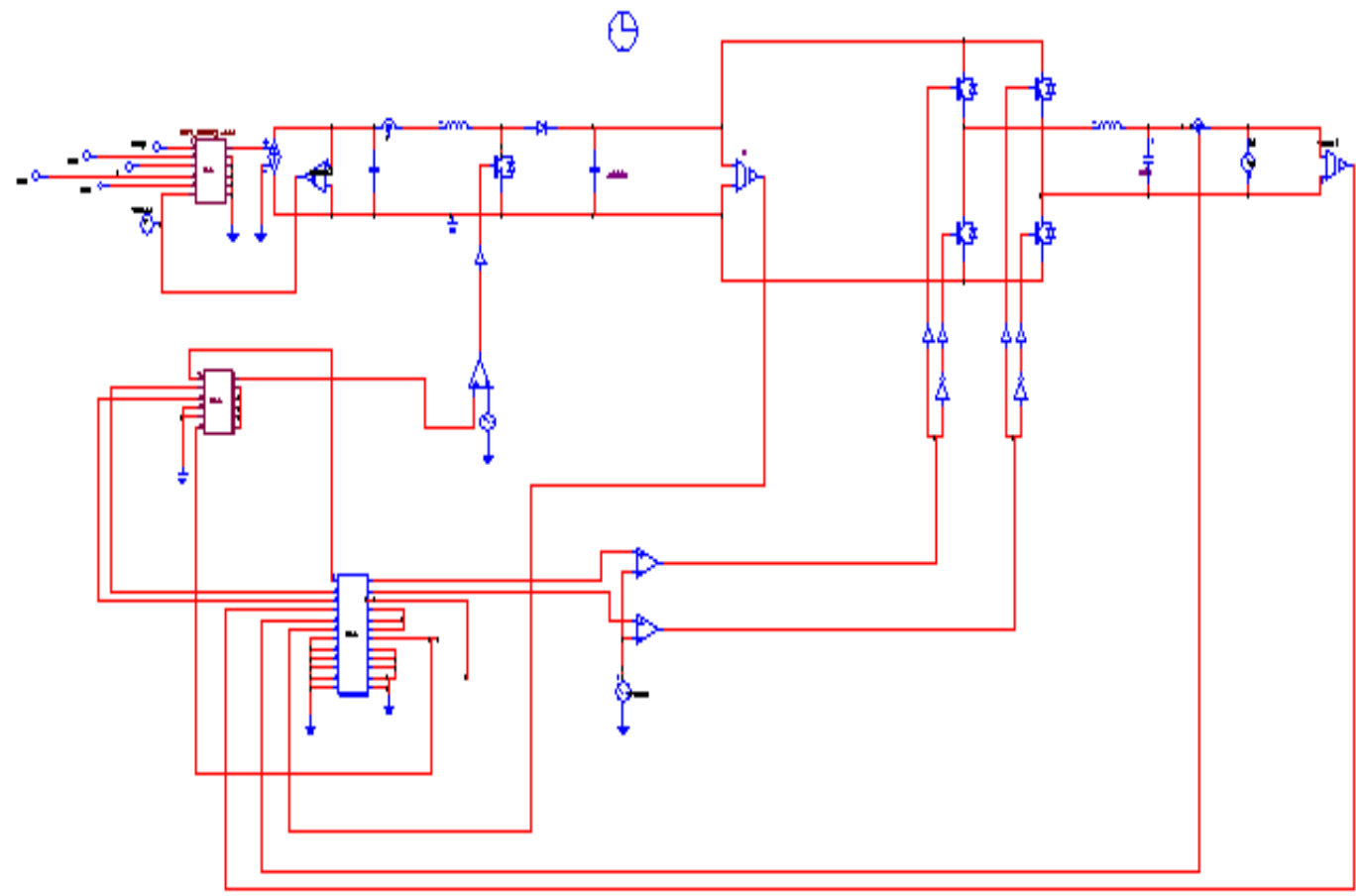

Fig. 7. Detailed model and control scheme of the grid-connected PV solar system in the PSIM environment.

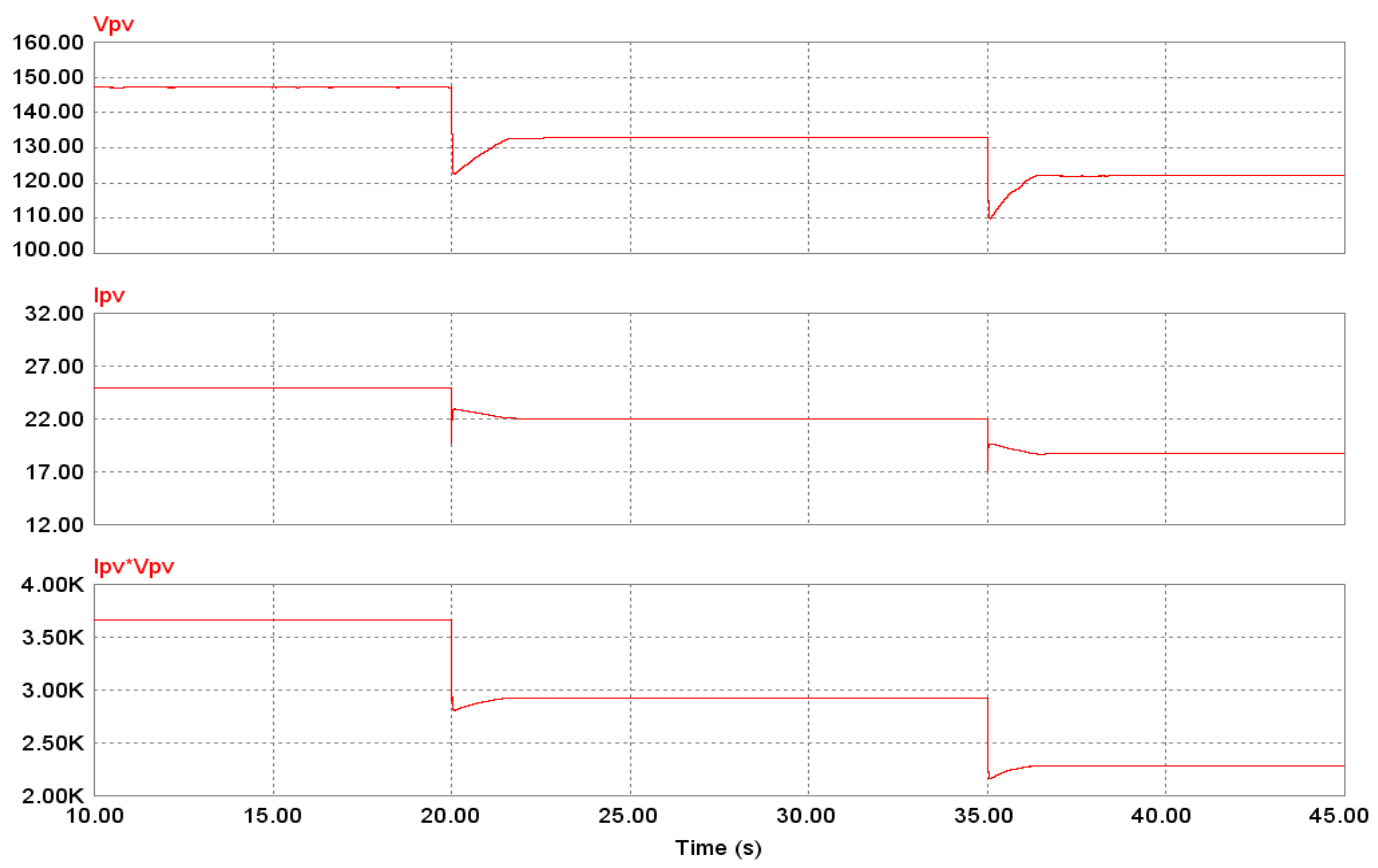

Fig. 8. PV voltage, current and power at different illumination levels. 


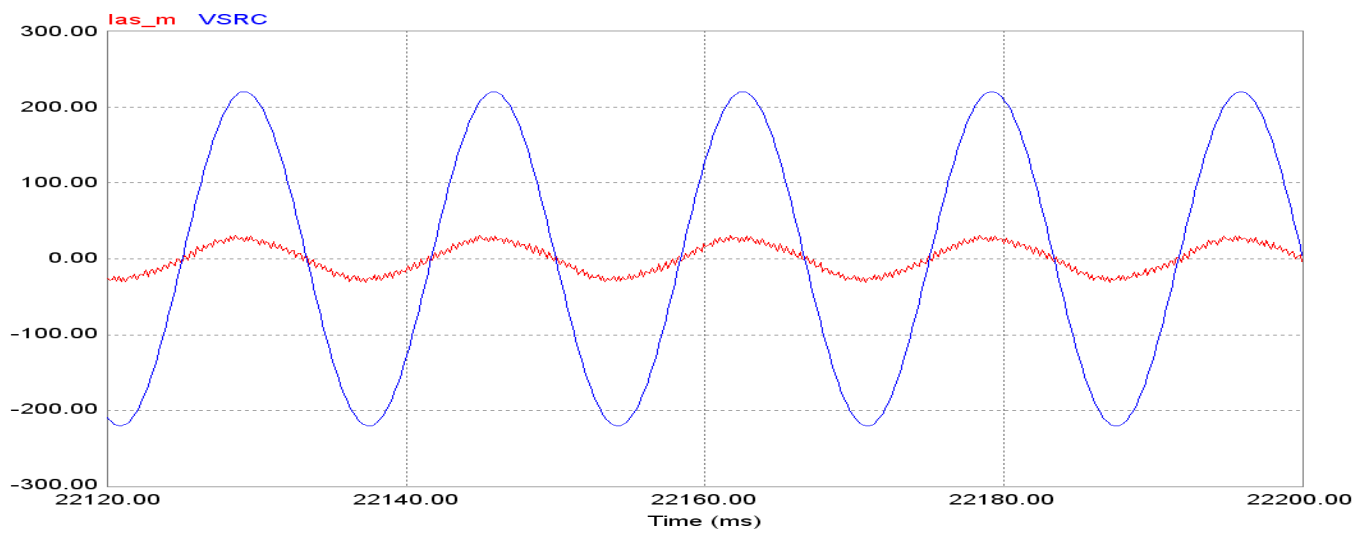

Fig. 9. Instantaneous grid voltage and current waveforms.
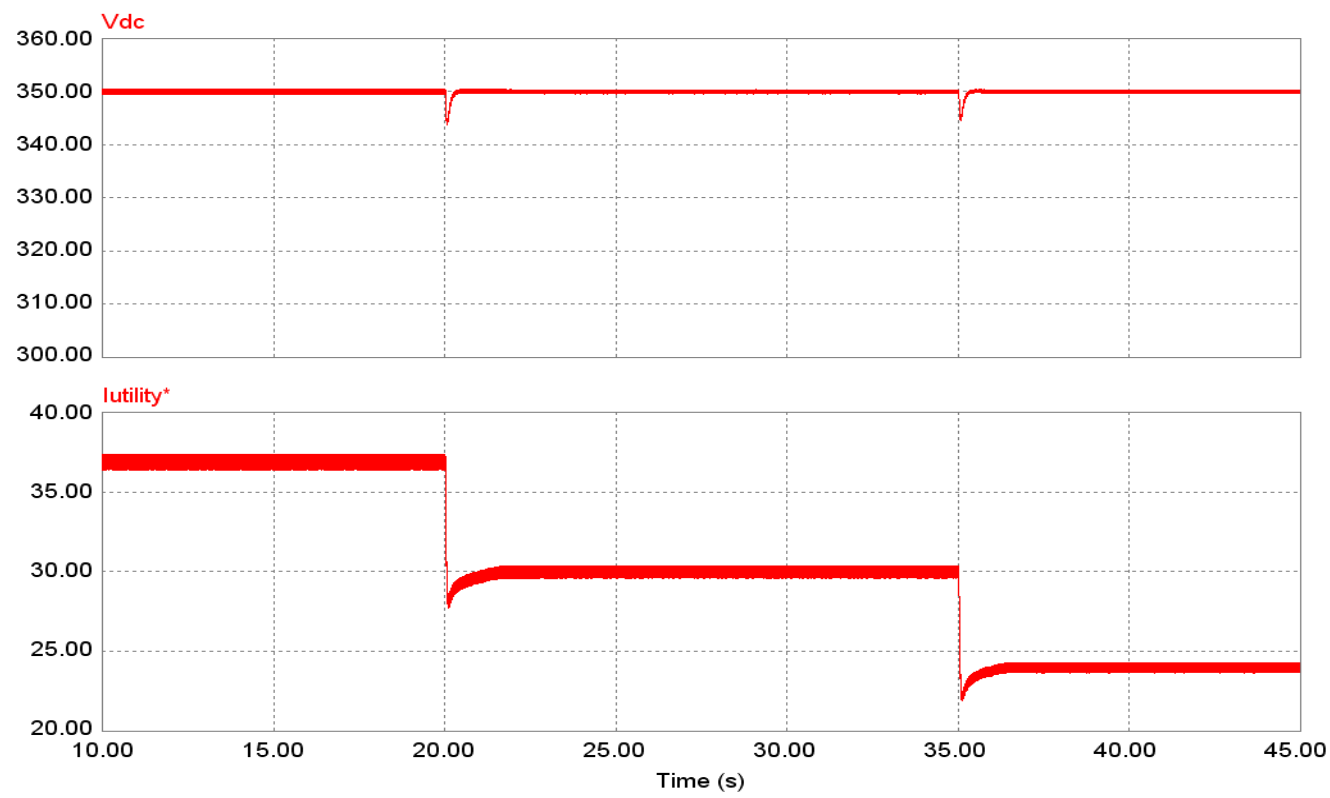

Fig. 10. Transients of the DC link voltage and utility reference current.

\section{6- CONCLUSIONS}

This paper is focused on the modeling, design, and simulation of a grid connected photovoltaic system controlled by the voltage oriented control for an apartment in new Assiut city, Assiut. The paper suggests load profiles, sizing of a PV system supplying the electrical load of the apartment using Hybrid Optimization Model for Electric Renewable (Homer) software. The simulation results show excellent dynamic response despite the rapid change in the illumination level and power. Also, the conversion system provides smooth and stable operation. 


\section{7- References}

[1] W. Xiao, N. Ozog, and W. G. Dunford, "Topology study of photovoltaic interface for maximum power point tracking," IEEE Trans. Ind. Electron., vol. 54, no. 3, pp. 1696-1704, Jun. 2007.

[2] L. Chang and H.M. Kojabadi, "Review of interconnection standards for distributed power generation," Large Engineering Systems Conference on Power Engineering 2002 (LESCOPE' 02), pp.36 - 40, June 2002.

[3] N. Patcharaprakiti and S. Premrudeepreechacharn, "Maximum power point tracking using adaptive fuzzy logic control for grid-connected photovoltaic system”, in IEEE Power Engineering Winter Meeting, 2002.

[4] Soeren B. Kjaer, John K. Pedersen and Frede Blaabjerg, "A Review of SinglePhase Grid-Connected Inverters for Photovoltaic Modules," IEEE Transactions on Industry Applications, Vol. 41, No. 5, Sep. 2005.

[5] A. A. Hassan1, A. A. Nafeh1, F. H. Fahmy, Mohamed A. El-Sayed, "Stand-Alone Photovoltaic System for an Emergency Health Clinic," Proc. International Conference on Renewable Energies and Power Quality (ICREPQ'10), March 2010.

[6] Egyptian solar radiation atlas, Cairo, Egypt, 1998.

[7] B. G. YU, A. G. Abo-Khalil, M. Matsui, G. J Yu, " Sensorless Fuzzy Logic Controller for Maximum Power point Tracking of Grid, "IEEE proc. of International Conference on Electrical Machines and Systems, vol. 1, Dec. 2009.

\section{نمذجة و محاكاة لنظام طاقة ضوئية متصلة بالشبكة الكهربائية للحصول على مصدر طاقة}

\section{كهريائية لتغذية شقة متوسطة الاستهلاك فى مدينة اسيوط الجديدة}

يقدم هذا البحث نموذج كامل وتصميم نظام لاستخدام الطاقة الشمسية المتصلة بالثبكة الكهربائية فى تغذية شقة

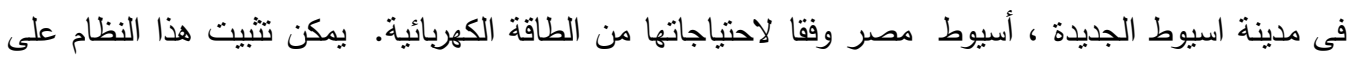

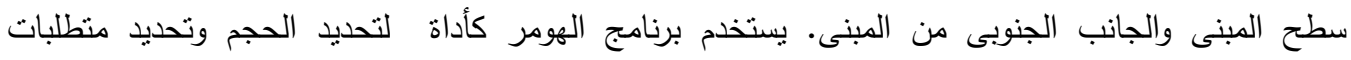
مواصفات مكونات نظام الطاقة الثمسية و نحديد نكلفة النظام و تقدير الطاقة الكهربائية المنتجة الدقابلة. يتم عرض نتائج المحاكاة والتحليلات للنحقق من صحة تكوين نظام الطاقة الثمسية المقترح. 